\title{
Açık ve Yeşil Alanların Çok Ölçütlü Algı Değerlendirmesi
}

\author{
Elvan ENDER ALTAY ${ }^{1 *}$, Zeynep PİRSELIMOĞLU BATMAN ${ }^{1}$ \\ ${ }^{1}$ Bursa Uludağ Üniversitesi, Ziraat Fakültesi, Peyzaj Mimarlığı Bölümü, 16059, BURSA
}

\section{Öz}

Günümüzde kentsel yaşamın en yaygın kullanım alanları açık ve yeşil alanlardır. Açık ve yeşil alanların işlevsel ve estetik olmalarının yanı sıra kullanıcıları tarafından nasıl algılandıkları da önemlidir. Algı ve değer oluşumu, insan - mekân arasındaki ilişsiyi sağlayan parametrelerden biri olarak ele alınmalıdır. Yeşil alanlar bu ilişkiyi sağlarken, yol ve yön bulmaya yardımcı olur, yönelme sağlar, deneyim kazandırır ve mekânsal niteliğin artırılmasına katkıda bulunur. Bu çalışma, açık ve yeşil alanlarda mekânsal niteliğin artırılması hedefiyle yapılmış olup Bursa Uludağ Üniversitesi Ziraat Fakültesi çalışma alanı olarak seçilmiştir. Çalışmada, öğrencilerin ve çalışanların Bursa Uludağ Üniversitesi Ziraat Fakültesi dış mekânlarını nassıl algıladıkları ve mekânı nasıl tanımladıklarını belirleyebilmek amaçlanmıştır. Bu amaçla, 44 ölçüt çalışma alanında ağırlıklandırılmış ölçütler yöntemi ile değerlendirilmiştir. Sonuç olarak, mekânın toplam puanı 569,77 olup, $\% 55,11$ 'i pozitif mekân olarak değerlendirilmiştir. Araştırma alanı, en yüksek puan alan ölçütlerle tanımlandığında, insan ölçeğiyle uyumlu, aydınlık ve yumuşak mekan olarak değerlendirilmiştir. En düşük ölçüt puanları ile mekânın olumsuz özellikleri ise, biçim ve form etkisinin olmaması ve sıra dışı (şaşırtıcı/sürprizli) mekânların bulunmamasıdır.

Anahtar Kelimeler: Açık ve yeşil alanlar, Bursa Uludağ Üniversitesi Ziraat Fakültesi, mekânsal algı, pozitif mekân.

\section{Multi-Criteria Perception Assessment of Open and Green spaces}

\begin{abstract}
Today, the most common usage areas of urban life are open and green spaces. In addition to being functional and aesthetic, it is also important how open and green spaces are perceived by their users. Perception and value formation should be considered as one of the parameters that provide the relationship between human and space. While providing this relationship, it helps to find path and direction, provides orientation, provides experience and contributes to increasing spatial quality. This study was carried out with the aim of increasing the spatial quality in open and green spaces and Bursa Uludağ University Faculty of Agriculture has been selected as the study area. In this study, it is aimed to determine how students and employees perceive the outdoor areas of Bursa Uludağ University Faculty of Agriculture and how they define the space. For this purpose, 44 criteria were evaluated by weighted criteria method in the study area. As a result, the total score of the space was 569,77 and $55,11 \%$ was evaluated as positive space. When the study area was defined by the highest scoring criteria, it was evaluated as a compatible with the human scale, bright and soft space. The lowest criterion scores and the negative features of the place are the shape effect and form effect and the absence of unusual (surprising / surprising) spaces.
\end{abstract}

Keywords: Bursa Uludag University Faculty of Agriculture, open and green spaces, positive space, spatial perception. 


\section{Giriş}

Psikoloji ile bilişsel bilimlerde duyusal bilgi alımı olarak kullanılan algı, insan ve bulunduğu çevrenin kimliğinin insandaki anlamıyla ilişkilendirilmesinde önemli bir araçtır. Temel olarak algı, çevreden gelen verilerin mekânı kullananların zihninde gruplanarak bütünleştirilmesi ve anlamlandırılması şeklinde tanımlanmaktadır (Norberg-Schulz, 1966). Mekânsal algı ise alan ve mekânlar bütününün anlaşılması ve değerlendirilmesinde önemli görev üstlenmekte, yol ve yön bulmaya yardımcı olmakta, yönelme sağlamakta, deneyim kazandırmakta ve mekânsal niteliğin artırılmasına katkıda bulunmaktadır (Türkoğlu, 2002). Mekânsal algılama, ilk imaj ya da imge ile başlayıp anlam yüklemeye uzanan bir süreçtir. İnsanların mekânlara yönelip, belli etkileşimlerde bulunması ve bu alanları daha da belirginleştirmesi ile kentsel mekânların sınırları daha net ortaya çıkmaktadır. Mekânlar bu durumlarda hissedilir ve izlenir duruma gelebilmektedir. Sınırlandırılmamış, sonsuz mekân sadece düşünülebilir olup, algılanamaz. Bu durumda mekân; fiziksel olarak herkes tarafindan erişilebilir ve tanımlanabilir bir yer olarak vurgulanmıştır (Madanipour, 1999; Altan, 2017).

Mekânsal algılama, ilk imaj ya da imge ile başlayıp anlam yüklemeye uzanan bir süreçtir. Çevremizdeki olay ve değişimler duyu organlarımızı etkileyen bir bütün olarak değerlendirildiğinde, duyarlı olduğumuz olay ve değişimlerle birlikte mekân konusunda bilgilenerek, mekâna anlam yükleyebiliriz. Bir başka deyişle, kullanıcı ile mekân arasındaki etki ve tepki ilişkileri sırasında kullanıcı, mekânın onun için herhangi bir şekilde anlam taşıyan öğelerini algılar. Kentsel mekânlarda, her durumda bir duyunun işin içine girmesiyle keşfedilebilecek manzaralar bulunmaktadır ve mekânsal algılamaya etki eden dört duyu sırasıyla, görme, dokunma, işitme ve koku alma duyusu olarak saptanmıştır. Mekânın pozitif tanımlanması toplu bir algılama gerektirir. Hatta bazı durumlarda, duyma, koklama, dokunma görmeden daha öncelik taşıyabilmektedir. Bu öncelik kullanıcıya göre işitme, görme, koku alma, dokunma duyusu olarak değişiklik gösterebilmektedir. Bu durumda duyumsal hazların artırılması için mekânların pozitif mekân olarak tanımlanması yani olumlu etki bırakacak şekilde tasarlanması gerekmektedir (Lynch, 1973; Yücel, 1981; İnceoğlu ve Aytuğ, 2009; Atanur, 2010; Konaklı ve ark. 2010; Altan, 2017). Mekânlar kapalılık ile ilişkili olarak negatif mekânlar ve pozitif mekânlar olarak iki grup altında toplanır. Negatif mekân, belirli bir biçimi olmayan, yapılar/binalar inşa edildikten sonra geriye kalan hacimler olarak değerlendirilir. Pozitif mekânlar ise, kesin ve belli bir biçimi olan mekânlar olarak tanımlanır. Negatif mekân ile pozitif mekân arasındaki en önemli farklılık işlevlerindedir. Pozitif mekânlar insanların kendilerini içinde rahat hissettikleri ya da kullanmayı tercih ettikleri, negatif mekânlar ise göreli olarak rahat hissetmedikleri ve kullanmayı tercih etmedikleri mekânlardır (Ashihiara, 1981; Öksüz, 2004).

Mekânlardaki algı ve olumlu etkiler bütünleşme aracı olmakla birlikte, kullanıcılarının kültürel birikimlerini paylaşmasına ve aktarmasına olanak tanıyabilmektedir. Bu durumda mekân-insan arasındaki ilişkiyi ortaya çıkarabilmek için kullanıcılar tarafından mekânların nasıl algılandığı önemlidir. Bütün bu algılama süreci kişiye göre değişkenlik gösterebilmektedir (İnceoğlu ve Aytuğ, 2009; Lynch, 1973). Kullanıcıların farklı mekânlarla, farklı sürelerde ilişkilerinin olması bu değişkenliği açıklayabilir (Lynch, 1973). Mekânlardaki fiziksel niteliklere bağlı uyarıcılar; kullanıcının sosyo-psikolojik ya da fizyolojik özellikleri de, her bir kullanıcı için özgün mekân algısının ortaya çıkmasına imkân sağlamaktadır. Fizyolojik süreçte kendini var eden ilk imaja yönelik yorumlar sadece algılayıcıya bağlı olarak değil, algılanan mekânın niteliğine bağlı olarak da farklılık sunabilecektir (Rapoport, 1977; Başkaya ve ark., 2003). Mekânın estetik özellikleriyle birlikte fonksiyonuna cevap verebilme performansı, o mekân hakkındaki görüşleri etkileyebilmektedir. Aynı zamanda mekânda yönelme, kalma süresi, kullanım çeşitliliği ile mekânı kullanma sıklığı, mekânın özellikleri ve mekânı algılamayla birlikte mekânı deneyimleme sürecini güçlendirebilmektedir.

Mekânsal davranışsal başarımı (performansı) yüksek olan mekânlar; kullanıcıların ihtiyaçlarına hizmet edebilen ve pozitif algılanan mekânlar olarak düşünüldüğünde ihtiyaca yanıt veren mekânların birtakım ölçütler dikkate alınarak tasarlanması gerekmektedir. Herkese açıklık ile tarif edilen yani genel kullanıma izin veren kamusal mekânlar kapsamında açık ve yeşil alanlarda mekânsal algı kavramı, kullanıcı kitlesi yoğun olduğu için, önemli bir olgudur (Glazer ve Lilla, 1987). Açık ve yeşil alanlar, kullanıcıları üzerinde etkisi büyük olan kent bileşenlerinden olup çevresinin deneyimini ve birikimini ortaya koymaktadır. Üniversite yerleşkelerinde yapılar dışında kalan alanların önemli bir bölümü açık ve yeşil alanlara ayrılmıştır. Üniversitelerdeki aktif ve pasif etkinliklere olanak veren yeşil alanlar dışında kalan ulaşım ağları, bisiklet yolları, meydanlar, otoparklar, girişler, toplanma alanları ise açık alanları oluşturmaktadır (Dober 1992).

Açık ve yeşil alanların tasarımlarında, mekânın belirlenen ihtiyaca ulaşıp ulaşmadığı, ortaya koyduğu başarım (performans) ile değerlendirilir.

$\mathrm{Bu}$ bağlamda çalışmada, mekânsal algının irdelenebilmesi için mekânı tanımlayabilecek ölçütler ortaya konulmaya çalışılmış, bu ölçütlerle Bursa Uludağ Üniversitesi Ziraat Fakültesi yerleşkesinde mekânsal algı üzerine odaklanılmıştır. 


\section{Materyal ve Metot}

\subsection{Materyal}

Bu çalışmada Bursa Uludağ Üniversitesi Ziraat Fakültesi açık ve yeşil alanları materyal olarak seçilmiştir. Araştırma alanı Nilüfer ilçesindedir (Şekil 1). Ziraat Fakültesi'nde, 130 akademik personel, 36 idari personel ve 2303 öğrenci olmak üzere toplam 2469 kullanıcı bulunmaktadır. Fakülte yerleşkesi toplam $41800 \mathrm{~m}^{2}$ yüzölçümüne sahiptir. Toplam açık ve yeşil alan miktarı ise $33865 \mathrm{~m}^{2}$ 'dir (URL-2, 2019). Çalışmada fakülte yerleşkesinde bulunan otopark, ulaşım ağları ve toplanma alanları açık alanlar, oturma birimlerinin de bulunduğu fakülte bahçesi yeşil alanlar kapsamında incelenmiştir. Çalışma alanının fotoğrafları Şekil 2'de verilmiştir.

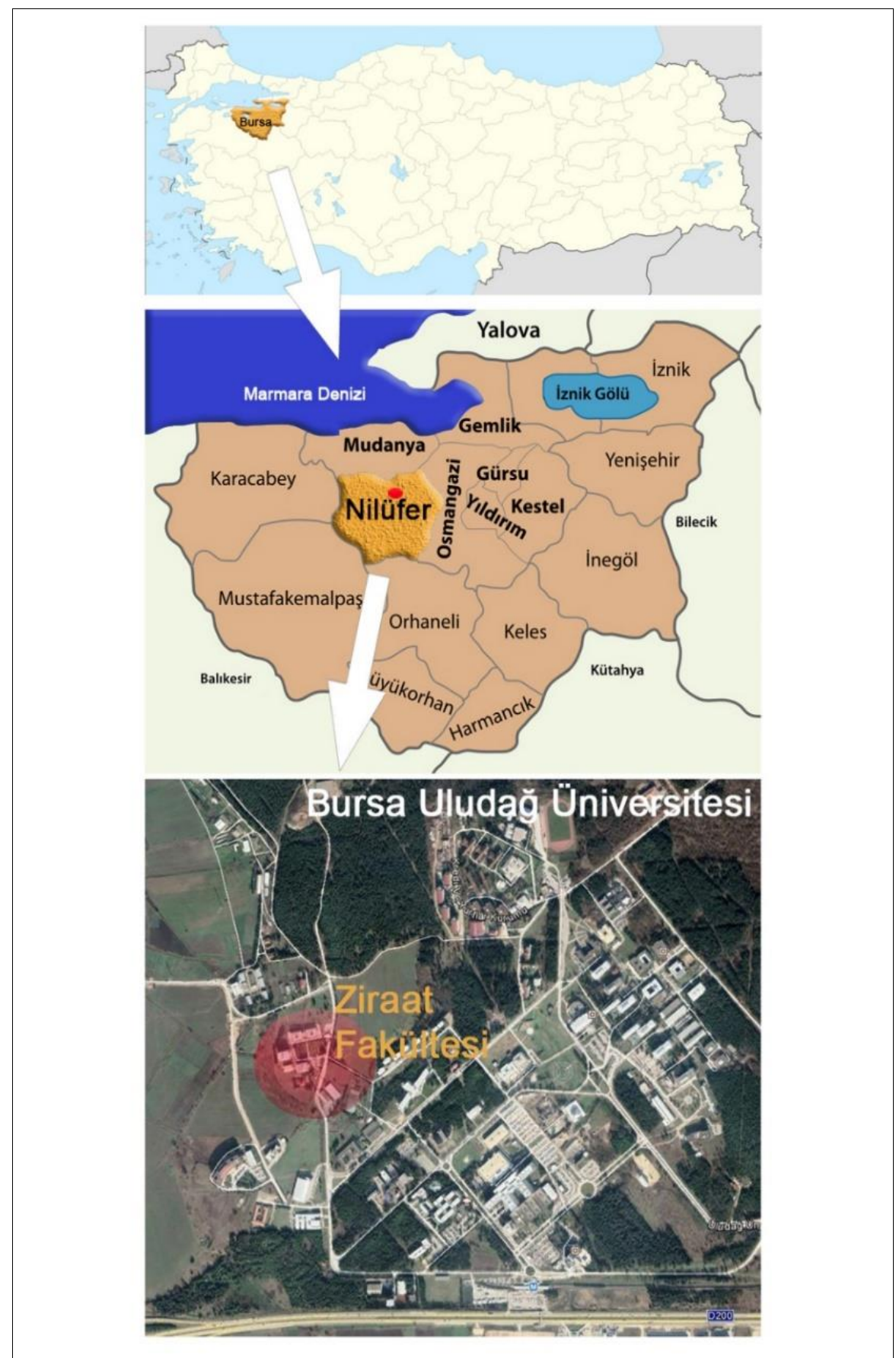

Şekil 1. Araştırma alanının konumu (URL-1, 2018) 


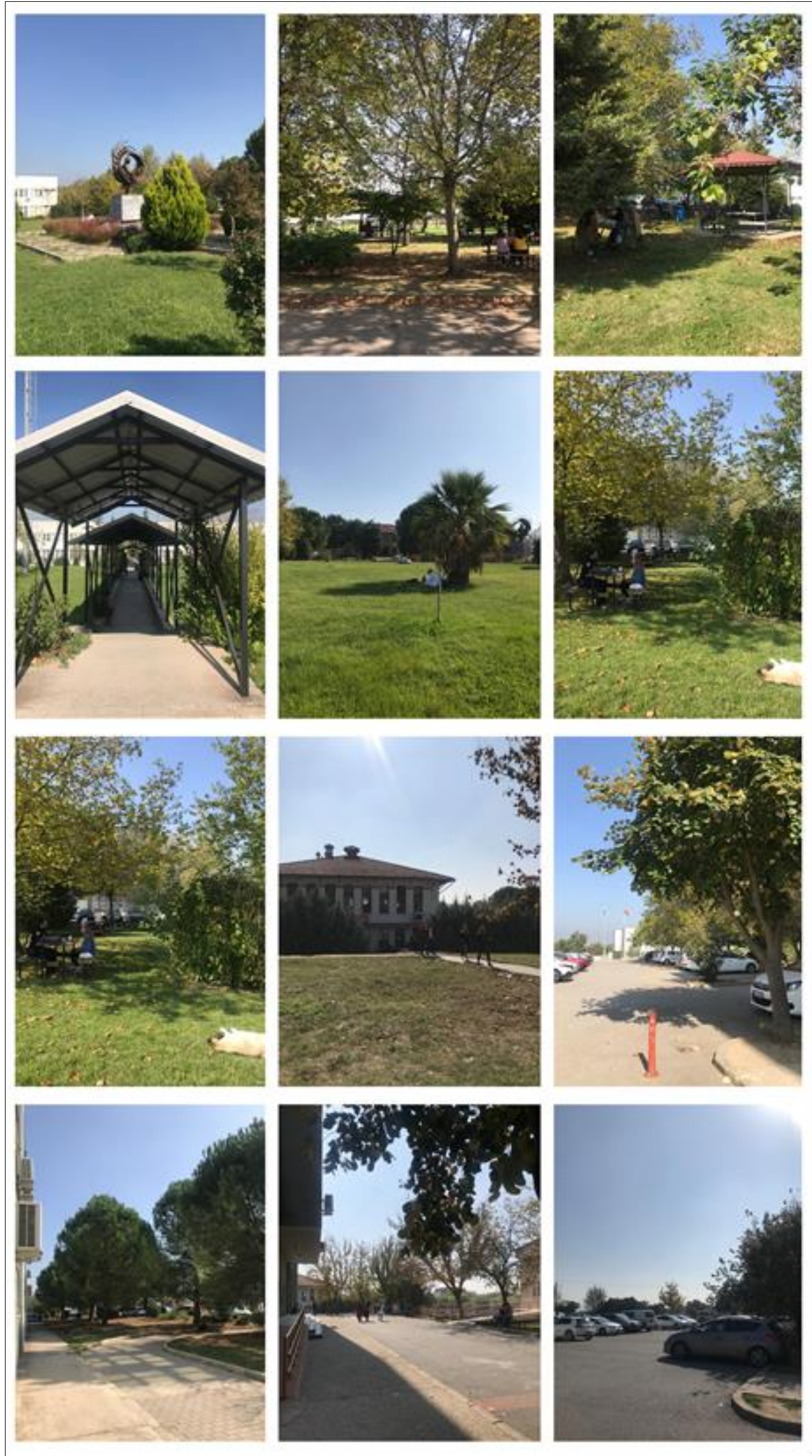

Şekil 2. Araştırma alanının fotoğrafları 


\subsection{Metot}

Bu çalışmada Bursa Uludağ Üniversitesinde mekânsal algının değerlendirilebilmesi için ilk olarak Gold (1980) tarafindan Santa Barbara kenti (ABD) örneğinde açıklanan, Altunkasa ve Yücel (1998), Altunkasa ve ark. (1999), Uslu ve ark. (2004), Y1lmaz (2006), Gültekin (2007), Demirel (2008), Ender (2011) ve Kalkan (2014) tarafından bisiklet yolu, meydan ve yaya yolu gibi kentsel donatıların değerlendirilmesinde kullanılan ve başarılı sonuçlar verdiği adı geçen araştırmacılar tarafından vurgulanan "Ağırlıklandırılmış Ölçütler Yöntemi" temel alınmıştır. Yöntemin ilk aşamasında, açık ve yeşil alanlarda mekânsal algıyı değerlendirme ölçütleri belirlenmiştir. Bu amaçla mekânsal algı konusunda yurt içinde ve yurt dışında yapılmış araştırmalar incelenmiştir. Mekânsal alg1 ve mekânsal kalite ile ilgili Lynch (1973), Başkaya ve ark., (2003), Özer ve Ayten (2005), Watson ve Bentley (2008), Temelli (2008), İnceoğlu ve Aytuğ (2009), Konaklı ve ark., (2010), Altunkasa ve Uslu (2016), Ender (2017), Altan (2017), Project for Public Spaces (PPS) (2018)'in yaptıklar1 çalışmalardan geliştirilerek mekânın pozitif tanımlanmasına yardımcı olabilecek ve çalışma kapsamında kullanılmak üzere 44 ölçüt belirlenmiştir. Bu ölçütler Tablo 1'de verilmiştir.

Tablo 1. Mekânsal algıyı değerlendirme ölçütleri

\begin{tabular}{|c|c|c|c|}
\hline Algı ölçütü & $\begin{array}{c}\text { Algı ölçütü } \\
\text { (yakın anlamı) }\end{array}$ & Algı ölçütü & $\begin{array}{c}\text { Algı ölçütü } \\
\text { (yakın anlamı) }\end{array}$ \\
\hline Renk Kullanımı & Renk Etkisi & Devinduyum & Kinestetik/Hareket Duyumu \\
\hline Biçim Kullanımı & Biçim Etkisi & Bireysel Gelişime Açık & $\begin{array}{c}\text { Mekâna İlişkin Açık İmge } \\
\text { Bulundurma }\end{array}$ \\
\hline Doku Kullanımı & Doku Etkisi & Düşünmeye imkan veren & \\
\hline Form Kullanımı & Form Etkisi & Spiritüel Bağlantı & \\
\hline Işık Kullanımı & Iş1k Etkisi & Yumuşak Mekân & Doğaya Yakınlık \\
\hline Görsel Tatmin & & Aidiyet Hissi & \\
\hline İşitsel Tatmin & Ses Etkisi & Samimi & Sicak \\
\hline Kokusal Tatmin & Koku Etkisi & Güven Yaratan & \\
\hline Dokunsal Tatmin & $\begin{array}{c}\text { Dokunma Etkisi } \\
\text { Kolay Algılanabilirlik }\end{array}$ & Aydınlık & Karanlık Olmayan \\
\hline Tanımlanabilirlik & $\begin{array}{c}\text { Karmaşık Olmayan } \\
\text { Karmaşadan Uzak }\end{array}$ & Özgürlük Hissi & \\
\hline Okunaklılık/Açıklık & Netlik & Rahatlık Hissi & \\
\hline Fonksiyonellik & İşlevsel Uygunluk & Sıra dışı & Şaşırtıc1 \\
\hline Tasarımda Çeşitlilik & Tekdüze Olmayan & İlgi Çekici & $\begin{array}{c}\text { Sürprizli } \\
\text { Sıkıcı Olmayan }\end{array}$ \\
\hline Sürdürülebilirlik & & Canlandırıcı & Uyarıcı \\
\hline $\begin{array}{l}\text { Denge İlkesine } \\
\text { Uygunluk }\end{array}$ & Dengeli & Devingen & $\begin{array}{c}\text { Durağan Olmayan/Durgun } \\
\text { Olmayan }\end{array}$ \\
\hline $\begin{array}{l}\text { Düzen İlkesine } \\
\text { Uygunluk }\end{array}$ & Düzenli & Huzur Verici & Ferah \\
\hline Bütünleşik Tasarım & Mekânsal Bütünlük & Konforlu & \\
\hline Mekân İçinde Uyum & & Renkli & $\begin{array}{c}\text { Canl1 } \\
\text { Soluk Olmayan }\end{array}$ \\
\hline Çevreyle İlişkili & Çevreyle Uyumlu & Modern & $\begin{array}{l}\text { Modası Geçmemiş } \\
\text { Günümüze Uygun }\end{array}$ \\
\hline Yön Bulabilme & $\begin{array}{l}\text { Kolay Hareket Edebilme } \\
\text { Yön Duygusu Oluşturma }\end{array}$ & Estetik & Güzelduyu \\
\hline $\begin{array}{l}\text { İnsan Ölçeğiyle } \\
\text { Uyumlu }\end{array}$ & İyi Ölçeklilik & Bakımlı & \\
\hline $\begin{array}{l}\text { Endişe ve Korkudan } \\
\text { Uzak }\end{array}$ & Yüreklendirici & Tercih Edilebilir & Kullanmayı Yeğlerim \\
\hline
\end{tabular}

Araştırma için değerlendirilen her algı ölçütü kendi ölçüt durumu açısından önemli olmakla birlikte, tüm ölçütler karşılaştırıldığında her birinin önem düzeyleri arasında farklılıklar ortaya çıkabilecektir. Bu amaçla, fiziksel planlama ve tasarım ile ilgili 30 uzmanla (peyzaj mimarları, mimarlar ve şehir bölge plancıları) karşılıklı görüşme ve örgün ağdan iletişim ile standart formlarla anket çalışması uygulanmıştır. Ölçütlerin önem düzeyi puanları, 1 ile 5 arasında değișen cetvel aracılığı ile sorgulanmıştır. 1; en düşük önem düzeyi puanı, 5; en 
yüksek önem düzeyi puanıdır. Anket çalışması ile sorgulanan etkinlik puanlarının aritmetik ortalamaları alınarak her bir ölçüt için ayrı ayrı önem düzeyi katsayısı hesaplanmıștır. Her bir ölçüt için verilen puan ile ölçütün katsayısı çarpılarak her ölçüt için ağırlıklı puanlar elde edilmiştir. Bu işlemi aşağıda verilen formülle özetlemek mümkündür.

$$
\text { Ağırlık Puanı a = (Katsayı a) x (Ölçüt a) }
$$

Aşağıdaki formül ile 44 ölçütün ağırlıklı puanlarının toplanması ile araştırma alanının toplam puanına ulaşılmıştır.

Toplam Ağırlık Puamı $=\sum_{\mathrm{n}=1}^{\mathrm{n}} \mathrm{K}_{1_{\mathrm{m}} \mathrm{n}} \mathrm{xO}_{1_{\mathrm{m}} \mathrm{n}}$

Sonraki aşamada ise mekânın pozitif tanımlanma düzeyinin belirlenmesi için mekânın alabileceği en yüksek puan ile araştırma alanının puanı arasındaki oransal değer (\%) hesaplanmıştır. Belirlenen ölçütlerden elde edilecek en yüksek puan her ölçütün önem düzeyi ile alabileceği en yüksek değer çarpılarak elde edilmiştir. Bu işlemleri aşağıda verilen formüllerle özetlemek mümkündür.

$$
\text { Mekâmın Alabileceği En Yüksek Ağırlıklı Puamı }=\sum_{n=1}^{n} K_{1_{\mathrm{mn}}} \times 0_{\max }
$$

Mekânun Pozitif Tammlanma Düzeyi $=\frac{\sum_{n=1}^{n} k_{1_{m} n} \times o_{1_{m} n}}{\sum_{n=1}^{n} k_{1_{m} n} \times o_{\max }} \times 100$

Ölçüt puanları, kullanıcılara yapılan anket sonucunda, her bir ölçüte verilen puanın ortalamasıyla belirlenmiştir. Anket yapılacak örneklem büyüklüğü aşağıdaki formülle hesaplanmıştır (Vural, 2012).

$$
\mathrm{n}=(\mathrm{Nt} 2 \mathrm{pq}) /(\mathrm{d} 2(\mathrm{~N}-1)+\mathrm{t} 2 \mathrm{pq})
$$

n: Örneklem büyüklüğü

$\mathrm{N}$ : Anakütle büyüklüğü (2469)

p: İlgilenilen olayın görülme olasılı̆̆ $(0,20)$

q: 1-p (veya ilgilenilen olayın görülmeme olasılı̆ğ) $(0,80)$

$\mathrm{d}$ : kabul edilen \pm örnekleme hata oranı $(0,05)$

t_( $\alpha, s d)$ : serbestlik derecesine göre $t$ tablosu kritik değeri $(1,96)$

$\overline{\mathrm{Bu}}$ formülden çıkan sonuçla toplam 224 kişiye yüz yüze anket uygulanmıştır.

Ağırlıklandırılmış ölçütler yöntemi sonucunda elde edilen puanlar dikkate alınarak mekânlardaki mekânsal başarımı yükseltebilecek ölçütler belirlenmiştir.

\section{Bulgular ve Tartışma}

Araştırmanın bulguları ölçüt katsayıları, ölçütün ağırlıklı puanları ve araştırma alanının toplam puanının hesaplanması başlıkları altında toplanmıştır.

\section{1. Ölçüt katsayıları}

Uzmanların ölçütlerin her birine verdiği önem düzeyleri ve ortalamaları Tablo 2'de verilmiştir. Ölçütlerin önem düzeyleri ağırlıklı puanları hesaplarken ölçütlerin katsayısı olarak kullanılmıştır. Katsayıların oransal dağılımı 3,21 ile 5 arasında değişmektedir.

Tablo 2 değerlendirildiğinde uzmanlara göre mekânın pozitif tanımlanabilmesi için, en yüksek puan alan, 21 ölçüt bulunmaktadır. Bu ölçütler Şekil 2'de verilmiştir. 
Tablo 2. Ölçüt katsayıları

\begin{tabular}{lclcc}
\hline Algı ölçütü & Katsayı & Algı ölçütü & Katsayı \\
\hline Renk Kullanımı & 4,88 & Devinduyum & 3,72 \\
Biçim Kullanımı & 3,21 & Bireysel Gelişime Açık & 4,22 \\
Doku Kullanımı & 4,92 & Düşünmeye imkan veren & 3,89 \\
Form Kullanımı & 3,65 & Spiritüel Bağlantı & 4,48 \\
Işık Kullanımı & 5 & Yumuşak Mekân & 5 \\
Görsel Tatmin & 5 & Aidiyet Hissi & 4,96 \\
İşitsel Tatmin & 5 & Samimi & 4,70 \\
Kokusal Tatmin & 5 & Güven Yaratan & 5 \\
Dokunsal Tatmin & 4,83 & Aydınlık & 5 \\
Tanımlanabilirlik & 5 & Özgürlük Hissi & 3,81 \\
Okunaklılı/Açıklık & 5 & Rahatlık Hissi & 4,96 \\
Fonksiyonellik & 5 & Sıra dışı & 4,92 \\
Tasarımda Çeşitlilik & 4,53 & İlgi Çekici & 5 \\
Sürdürülebilirlik & 4,78 & Canlandırıcı & 4,24 \\
Denge İlkesine Uygunluk & 4,76 & Devingen & 4,37 \\
Düzen İlkesine Uygunluk & 5 & Huzur Verici & 5 \\
Bütünleşik Tasarım & 5 & Konforlu & 5 \\
Mekân İçinde Uyum & 4,81 & Renkli & 5 \\
Çevreyle İlişkili & 4,37 & Modern & 3,89 \\
Yön Bulabilme & 5 & Estetik & 5 \\
İnsan Ölçeğiyle Uyumlu & 4,74 & Bakımlı & 5 \\
Endişe ve Korkudan Uzak & 5 & Tercih Edilebilir & 5 \\
\hline & & &
\end{tabular}

\begin{tabular}{|c|c|c|}
\hline Ișık Kullanımı Etkin & Endișe ve Korkudan Uzak & Yön Bulabilme Etkin \\
\hline Görsel Tatmin & Yumuşak Mekan & Bütünleșik Tasarıma Sahip \\
\hline İșitsel Tatmin & Güven Yaratan & Bakımlı \\
\hline Kokusal Tatmin & Aydınlık & Düzen İlkesine Uygun \\
\hline Tanımlanabilir & İlgi Çekici & Estetik \\
\hline Okunaklı/Açk & Huzur Verici & Renkli \\
\hline Fonksiyonel & Konforlu & Tercih Edilebilir \\
\hline
\end{tabular}

Şekil 2. En yüksek puan alan pozitif mekân ölçütleri

\section{2. Ölçütün ağırlıklı puanları}

Ölçütlerin ağırlıklı puanları Tablo 3'te verilmiştir. 
Tablo 3. Ağırlıklı ölçüt puanları

\begin{tabular}{|c|c|c|c|c|}
\hline Algı ölçütü & $\begin{array}{c}\text { Algı ölçütü } \\
\text { (Yakın anlamı) }\end{array}$ & Algı puanı & Katsayı & Ağırlıklı puan \\
\hline Renk Kullanımı & Renk Etkisi & 2,64 & 4,88 & 12,8832 \\
\hline Biçim Kullanımı & Biçim Etkisi & 2,32 & 3,21 & 7,4472 \\
\hline Doku Kullanımı & Doku Etkisi & 2,29 & 4,92 & 11,2668 \\
\hline Form Kullanımı & Form Etkisi & 2,36 & 3,65 & 8,614 \\
\hline Işık Kullanımı & Iş1k Etkisi & 2,46 & 5 & 12,3 \\
\hline Görsel Tatmin & & 2,36 & 5 & 11,8 \\
\hline İşitsel Tatmin & Ses Etkisi & 2,11 & 5 & 10,55 \\
\hline Kokusal Tatmin & Koku Etkisi & 2,11 & 5 & 10,55 \\
\hline Dokunsal Tatmin & $\begin{array}{c}\text { Dokunma Etkisi } \\
\text { Kolay Algılanabilirlik }\end{array}$ & 2,25 & 4,83 & 10,8675 \\
\hline Tanımlanabilirlik & $\begin{array}{c}\text { Karmaşık Olmayan } \\
\text { Karmaşadan Uzak }\end{array}$ & 3,18 & 5 & 15,9 \\
\hline Okunaklılık/Açıklık & Netlik & 3,04 & 5 & 15,2 \\
\hline Fonksiyonellik & İşlevsel Uygunluk & 3,00 & 5 & 15 \\
\hline Tasarımda Çeşitlilik & Tekdüze Olmayan & 2,57 & 4,53 & 11,6421 \\
\hline Sürdürülebilirlik & & 2,57 & 4,78 & 12,2846 \\
\hline Denge İlkesine Uygunluk & Dengeli & 2,64 & 4,76 & 12,5664 \\
\hline Düzen İlkesine Uygunluk & Düzenli & 2,68 & 5 & 13,4 \\
\hline Bütünleşik Tasarım & Mekânsal Bütünlük & 2,61 & 5 & 13,05 \\
\hline Mekân İçinde Uyum & & 2,64 & 4,81 & 12,6984 \\
\hline Çevreyle İlişkili & $\begin{array}{l}\text { Çevreyle Uyumlu } \\
\text { Kolay Hareket Etme }\end{array}$ & 3,04 & 4,37 & 13,2848 \\
\hline Yön Bulabilme & $\begin{array}{l}\text { Yön Duygusu } \\
\text { Oluşturma }\end{array}$ & 3,25 & 5 & 16,25 \\
\hline İnsan Ölçeğiyle Uyumlu & İyi Ölçeklilik & 4,04 & 4,74 & 19,1496 \\
\hline Endişe ve Korkudan Uzak & Yüreklendirici & 3,18 & 5 & 15,9 \\
\hline Devinduyum & $\begin{array}{l}\text { Kinestetik/Hareket } \\
\text { Duyumu }\end{array}$ & 2,93 & 3,72 & 10,8996 \\
\hline Bireysel Gelişime Açık & $\begin{array}{l}\text { Mekâna İliş̧kin Açık } \\
\text { İmge Bulundurma }\end{array}$ & 2,64 & 4,22 & 11,1408 \\
\hline Düşünmeye imkan veren & & 2,61 & 3,89 & 10,1529 \\
\hline Spiritüel Bağlantı & & 2,50 & 4,48 & 11,2 \\
\hline Yumuşak Mekân & Doğaya Yakınlık & 4,11 & 5 & 20,55 \\
\hline Aidiyet Hissi & & 2,86 & 4,96 & 14,1856 \\
\hline Samimi & Sicak & 3,00 & 4,70 & 14,1 \\
\hline Güven Yaratan & & 3,00 & 5 & 15 \\
\hline Aydınlık & Karanlık Olmayan & 4,07 & 5 & 20,35 \\
\hline Özgürlük Hissi & & 3,18 & 3,81 & 12,1158 \\
\hline Rahatlık Hissi & & 3,32 & 4,96 & 16,4672 \\
\hline Sıra dışı & $\begin{array}{l}\text { Şaşırtıcı } \\
\text { Sürprizli }\end{array}$ & 1,57 & 4,92 & 7,7244 \\
\hline İlgi Çekici & Sikıcı Olmayan & 2,25 & 5 & 11,25 \\
\hline Canlandırıcı & $\begin{array}{l}\text { Uyarıcı } \\
\text { Durağan }\end{array}$ & 2,39 & 4,24 & 10,1336 \\
\hline Devingen & $\begin{array}{l}\text { Olmayan/Durgun } \\
\text { Olmayan }\end{array}$ & 2,50 & 4,37 & 10,925 \\
\hline Huzur Verici & Ferah & 3,32 & 5 & 16,6 \\
\hline Konforlu & & 2,36 & 5 & 11,8 \\
\hline Renkli & $\begin{array}{c}\text { Canlı } \\
\text { Soluk Olmayan }\end{array}$ & 2,61 & 5 & 13,05 \\
\hline Modern & $\begin{array}{l}\text { Modası Geçmemiş } \\
\text { Günümüze Uygun }\end{array}$ & 2,32 & 3,89 & 9,0248 \\
\hline Estetik & Güzelduyu & 2,39 & 5 & 11,95 \\
\hline Bakımlı & & 2,89 & 5 & 14,45 \\
\hline Tercih Edilebilir & Kullanmayı Yeğlerim & 2,82 & 5 & 14,1 \\
\hline
\end{tabular}

Tablo 3'teki bulgulara göre ağırlıklı puanlar 7,4472 ile 20,55 arasında değişmektedir. Araştırma alanında en yüksek puan alan ölçütler insan ölçeğiyle uyumlu, aydınlık ve yumuşak mekân olarak bulunmuştur. En düşük ağırlıklandırılmış puana sahip ölçütler ise biçim etkisi, form etkisi ve sıra dışılıktır. 


\subsection{Araştırma alanının toplam puanının hesaplanması}

Tablo 3'te verilen 44 ölçütün ağırlıklı puanlarının toplanması ile araştırma alanının toplam puanına ulaşılmıştır. Araştırma alanının toplam puanı 569,7743'tür.

Bursa Uludağ Üniversitesi Ziraat Fakültesinin pozitif tanımlanma düzeyinin belirlenmesi için mekânın alabileceği en yüksek puan ise, tüm ölçütlerin algı puanı 5 olarak hesaplandığında, 1033,8'dir.

$\mathrm{Bu}$ hesaplamalar doğrultusunda araştırma alanı pozitif mekân tanımlamasının \%55,11'ini karşılamaktadır. Araştırma alanının uzmanlara göre mekânın pozitif tanımlanabilmesi için, en yüksek puan alan, 21 ölçütün mevcut durumlarının artırılmasıyla alanın toplam puanı daha da artırılabilecektir.

\section{Sonuç ve Öneriler}

Kullanıcı ihtiyaçlarına cevap veren mekânların işlevsel, estetik olmasının yanında duyularla da bağlantılı olması gerekmektedir. Mekânlar, fiziksel ve sosyal katmanlarının yanı sıra psiko-mekânsal katmanlara da sahip olan, sürekli yaşayan, değişen ve dönüşen canlı bir organizmaya benzemektedir (Kürkçüoğlu, 2015). Mekân ve kullanıcı arasındaki ilişki algı aracılığıyla kurulabilmektedir.

Bursa Uludağ Üniversitesi Ziraat Fakültesi örneklem alanında yapılan çalışmada, mekânsal algıyı değerlendirebilmek için 44 ölçüt bir araya getirilmiștir. Bu ölçütlerin değerlendirilmesi sonucunda mekânda biçim kullanımı, sıra dışlık, modernlik ve canlandırıcılık yetersiz bulunmuştur. Biçim, hacmin ve kütlenin tanımlanması, objelerin üç boyutlu algılanması olarak tanımlandığ için mekânlarda şekillerin birbirlerine göre yerleşimlerinin uygunluğu ile etkili hale getirilebilir. Algılamanın fiziksel boyutunun biçim etkisiyle ortaya çıkabilmesi için renk ve ışık ile de biçime canlılık kazandırılmalıdır. Araştırma alanında şaşırtıcı objeler, sürprizler içeren/ sıra dışı mekânlar oluşturarak mekânın farkındalığı artırılabilecektir.

Çalışmada katsayı olarak hesaplamalara dâhil edilen ve uzmanların cevapları sonucunda önem düzeyleri belirlenen ölçütlerden görsel tatmin, işitsel tatmin, kokusal tatmin, dokunsal tatmin yüksek önem düzeyine sahiptir. Öymen Özak ve Pulat Gökmen (2009) yaptıkların çalışmalarında, kullanıcıların anılarının ve ilgi alanlarının duyuların üzerindeki etkisiyle mekânı algılamalarındaki ölçütlerin önemlerinin değişebildiğini vurgulamış, mekânın algılanmasında önemli rol oynayan görme, işitme, koklama, tat alma ve dokunma gibi duyuları çalışmalarında değerlendirmişlerdir. Mekânlarda, işitme, koklama, tat alma ve dokunma duyularına hitap eden tasarımlarla mekânların pozitif mekân olarak tanımlanma olasılıkları artabilecektir.

Yapılan araştırma doğrultusunda çalışma alanı bütününde 44 ölçüt dikkate alınarak fakülte yerleşkesinin mevcut durumunu geliştirecek tasarım anlayışı benimsenmelidir. Araştırma alanına günümüze ve fakültenin özelliklerine uygun özgün donatılarla birlikte uyarıcı/canlandırıcı etkisi olan donatıların tesis edilmesinin araştırma alanını olumlu yönde etkileyeilecektir. Bu doğrultuda alan içerisinde oturma birimleri, masalar, çöp kutuları, aydınlatma elemanları, çeşmeler, yönlendirme/işaret levhaları gibi donatılar bir bütün halinde düşünülerek çalışmadaki algı ölçütleri ön planda tutularak tekrar tasarlanmalı, yeni donatılar eklenmelidir. Cansız materyalin yanı sıra canlı materyalde ölçütler doğrultusunda tekrar ele alınmalı, bakımı yapılmalıdır. Mekânların sahip olması gereken güven yaratma, aydınlık olma, yön bulma, sürdürülebilirlik, huzur verici olma, ilgi çekici olma, renkli olma, estetik olma durumları doğrultusunda bitkilendirme tasarımında iyileştirmeler yapılmalıdır. Açık ve yeşil alanlara kullanıcılarca anlam ve olumlu değerler yüklenmesi, bu alanların kentteki değerini artırabilecektir.

\section{Kaynaklar}

1. Ashihiara, Y. (1981). Exterior Design in Architecture, Van Nostrand Reinhold Press. New York.

2. Altan, İ. (2017). Mimarlıkta Mekân Kavramı. Ofis 2005 Yayınevi. İstanbul.

3. Altunkasa, M.F., Uslu, C. (2016). Peyzaj Tasarımı. Birsen Yayınevi. ISBN: 978-975-511-645-7. İstanbul.

4. Altunkasa, M.F., Yücel, M. (1998). Fahrradrouten als Element des Nahverkehrssystems im oberen Stadtentwicklungsgebiet Nord-West Adana. TU International, Nr. 42/43 Dezember, Berlin.

5. Altunkasa, M.F., Yücel, M., Yılmaz, K.T., Atmaca, M., İlter, A.A., Uslu, C. (1999). Çukurova Üniversitesi Kampusunda Fiziksel Planlamada Kullanılacak Verilerin Bilgisayar Yardımıyla Belirlenmesi. Ç.Ü. Ziraat Fakültesi Araştırma Projesi (BAP-PM-96/01), Adana (100 S.). 
6. Atanur, G. (2010). Kent Kimligi Cercevesinde Gorsel Peyzaj Degerlerinin Analizi - Mustafapasa Ornegi. Peyzaj Mimarlıgı IV. Kongresi Bildiriler Kitabı. İzmir.

7. Başkaya, A., Dinc, P., Aybar, U., Karakaslı, M. (2003). Mekânsal İmaj Uzerine Bir Deneme: Gazi Universitesi Muhendislik Mimarlık Fakultesi Egitim Blogu Giris Holu. Journal of the Faculty of Engineering and Architecture of Gazi University. Ankara.

8. Demirel, T. (2008). Kent Meydanları Yer Seçimine Metodolojik Bir Yaklaşım: Adana Kenti Örneği, Çukurova Üniversitesi Bilimleri Enstitüsü Peyzaj Mimarlı̆̆ı Anabilim Dalı,Yüksek Lisans Tezi, Adana.

9. Ender, E. (2011). Adana İli Çukurova İlçesi Aktif Yeşil Alanlarının Nitelik ve Nicelik Açısından İrdelenmesi, Çukurova Üniversitesi Bilimleri Enstitüsü Peyzaj Mimarlığı Anabilim Dalı, Yüksek Lisans Tezi, Adana

10. Ender, E. (2017). Cocuk Oyun Alanlarında Estetik Basarım, Journal of Bartin Faculty of Forestry. 19(1), 43.

11. Georgia-Watson, G., Bentley, I. (2007). Identity by Design. Elsevier Ltd., New York.

12. Glazer, N., Lilla, M.E. (1987). The Public Face of Architecture: Civic Culture and Public Spaces, Mac Millian, New York.

13. Gold, S.M. (1980). Recreation Planning and Design. McGraw-Hill, New York.

14. Gültekin, B. (2007). Kent İçi Yolların, Yaya Kullanımına Yönelik Değerlendirilmesinde Çözümlemeli Bir Yaklaşım: Adana Örneği. Çukurova Üniversitesi, Peyzaj Mimarlı̆̆ı Anabilim Dalı, Yüksek Lisans Tezi, Adana.

15. İnceoglu, M., Aytug, A. (2009). Kentsel Mekânda Kalite Kavramı. MEGARON. 4(3):131-146.

16. Kalkan, N. (2014). Malatya Kenti Aktif Yeşil Alanlarının Nitelik ve Nicelik Açısından İrdelenmesi, Çukurova Üniversitesi Bilimleri Enstitüsü Peyzaj Mimarlı̆̆ı Anabilim Dalı, Yüksek Lisans Tezi, Adana

17. Konaklı, N., Altunkasa, M.F., Uslu, C., Sirel, B. (2010). Mekânsal Algılama ve Mekânın Davranıssal Basarımı: Adana 5 Ocak ve Ugur Mumcu Meydanları Ornegi. Peyzaj Mimarlıgı IV. Kongresi Bildiriler Kitabı, İzmir.

18. Kürkçüoğlu, E. (2015). Kentsel Dokuda Mekânsal Yönelme Üzerine Bir Algı-Davranış Çalışması: Kadıköy Çarşı Bölgesi. MEGARON, 10(3), 365-388.

19. Lynch, K. (1973). The Image of the City, MIT Press, Cambridge, Massachusetts.

20. Madanipour, A. (1999). 'Why are the design and development of public spaces significant for cities', Environment and Planning B: Planning and Design, 26(6), 879-891.

21. Norberg-Schulz, C. (1971). Existence, Space \& Architecture, Studio Vista, London,

22. Öksüz, A. (2004). Kentsel Alanların Planlanması ve Tasarımı. Ilber Matbaacilık, Trabzon.

23. Öymen Özak, N., Pulat Gökmen, G. (2009). Bellek ve mekân ilişsisi üzerine bir model önerisi. İTÜ Mimarlı, Planlama, Tasarm Dergisi, 8(2), 145-155.

24. Özer, M.N., Ayten, M.A. (2005). Kamusal Odak Olarak Kent Meydanları. Planlama 2005/3. http://www.spo.org.tr/resimler/ekler/ 66d856efla6b02f_ek.pdf. Retrieved: 09.10.2018.

25. Project for Public Spaces (2018). http://www.pps.org. Retrieved: 10.11.2018.

26. Rapoport, A. (1977). Human Aspects of Urban Form: Towards a Man - Environment Approach to Urban Form and Design, Pergamon Press, UK.

27. Taşçığlu, S., Altunkasa, M.F. (2018). Kilis Kentsel Sit Alanında Kullanıcı Odaklı Mekânsal Algı Belirlemeleri. Inопи University Journal of Art and Design, 8(18), 1-15, Malatya.

28. URL-1 (2018). http://mmsrn.com. Erişim tarihi: 16.04.2019.

29. URL-2 (2019). http://uludag.edu.tr/ziraat. Erişim tarihi: 05.04.2019.

30. Uslu, C., Altunkasa, M.F., Yılmaz, E., Boyacıgil, O. (2004). Adana Kuzeydoğu Kentsel Gelişme Alanında Bisikletli Bağlantı Olanaklarının Araştırılması. Ç.Ü. Ziraat Fakültesi Dergisi, 19(3), Adana.

31. Vural, H. (2012). Tarım ve Gida Ekonomisi İstatistiği. Bursa: Uludağ Üniversitesi Ziraat Fakültesi Ders Notlar1 No: 107.

32. Yılmaz, E. (2006). Bolu Kentsel Alanında Bisikletli Bağlantı Olanaklarının Araştırılması. Yüksek Lisans Tezi, Çukurova Üniversitesi, Peyzaj Mimarlığı Anabilim Dalı, Adana. 